\title{
Cooking skills during the Covid-19 pandemic
}

\author{
Habilidades culinárias em tempos de pandemia \\ pela Covid-19
}

\author{
Paula Lazzarin UGGIONI1 ID 0000-0003-2696-0539 \\ Clarice Mariano Fernandes ELPO' ${ }^{1}$ (D) 0000-0002-5395-5033 \\ Ana Paula Gines GERALDO ${ }^{1}$ ID 0000-0002-9716-601X \\ Ana Carolina FERNANDES ${ }^{1}$ [D] 0000-0002-8179-4855 \\ Ana Cláudia MAZZONETTO' ${ }^{1}$ (D) 0000-0002-2009-592X

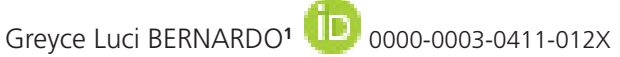

\section{A B S T R A C T}

This article aims to present reflections on cooking skills in times of the coronavirus disease 2019 pandemic. The current period of uncertainty and isolation heightens food insecurity issues, influencing food choice, purchase, and preparation. Social media and networks are sources of entertainment and learning, with vast resources for cooking skills, which can stimulate home cooking and strengthen family ties. Research has evidenced the positive relationship between cooking and diet quality, an important factor for groups at increased risk of severe illness from Covid-19. For some individuals, cooking may be a strategy to reduce anxiety and stress associated with the pandemic. However, the Brazilian reality is marked by inequalities in income and access to food. Thus, more vulnerable populations may not have the same relationship with cooking. Public policies should focus on food and nutrition programs and actions for the development of cooking skills as a means to promote healthy eating and encourage self-care.

Keywords: Covid-19. Disease prevention. Food and nutrition education. Healthy eating. Nutrition programs and policies. Social isolation.

\footnotetext{
1 Universidade Federal de Santa Catarina, Departamento de Nutrição, Programa de Pós-Graduação em Nutrição. R. Eng. Agronômico Andrei Cristian Ferreira, s/n., Trindade, 88040-900, Florianópolis, SC, Brasil. Correspondence to: G.L. BERNARDO. E-mail: <greyce.bernardo@ufsc.br>.

Support: The project did not receive any specific financial support. Financial aid was provided through scholarships granted by Programa Institucional de Bolsas de Iniciação (PIBIC, Institutional Scientific Initiation Scholarship Program), Coordenação de Aperfeiçoamento de Pessoal de Nivel Superior (Capes, Brazilian Federal Agency for Support and Evaluation of Graduate Education), and Conselho Nacional de Desenvolvimento Científico e Tecnológico (CNPq, Brazilian National Council for Scientific and Technological Development).
}

How to cite this article

Uggioni PL, Elpo CMF, Geraldo APG, Fernandes AC, Mazzoneto AC, Bernardo GL. Cooking skills during the Covid-19 pandemic. Rev Nutr. 2020;33:e200172. https://doi.org/10.1590/1678-9865202033e200172 


\section{RE S U M O}

Este artigo tem por objetivo apresentar considerações acerca de habilidades culinárias em tempos de pandemia pela Covid-19. O cenário vivenciado durante a pandemia, caracterizado pela incerteza e pelo isolamento, perpassa a questão de insegurança da alimentação, influenciando escolha, aquisição e preparo de alimentos, dentro e fora de casa. Mídias e redes sociais aparecem como alternativas de entretenimento e de aprendizado de habilidades culinárias, estimulando o preparo de refeições em casa e reforçando as relações familiares na cozinha. Evidências mostram relação da prática das habilidades culinárias com a qualidade da alimentação, que é condição significativa principalmente no cuidado com os indivíduos classificados como grupo de risco para Covid-19. Cozinhar, para alguns individuos, pode ainda ser uma estratégia para reduzir sentimentos como estresse e ansiedade, comuns no contexto da pandemia. A realidade brasileira, no entanto, é marcada por desigualdades tanto de acesso como de renda, de forma que populações mais vulneráveis podem não ter essa mesma relação com o ato de cozinhar. Nesse sentido, sugere-se investir em políticas públicas de alimentação e de nutrição que executem programas e ações para desenvolvimento de habilidades culinárias, visando à promoção da alimentação saudável e ao estímulo ao autocuidado.

Palavras-chave: Covid-19. Prevenção de doenças. Educação alimentar e nutricional. Alimentação saudável. Programas e políticas de alimentação e nutrição. Isolamento social.

\section{INTRODUCTION}

Discussions about cooking skills in times of the coronavirus disease 2019 (Covid-19) pandemic stem from the concern of the effects of social distancing, which has transformed the dietary habits of individuals in Brazil and around the world [1,2].

The most recent Brazilian Consumer Expenditure Survey, carried out in 2017-2018, revealed that the consumption of ultraprocessed foods has increased in detriment to that of fresh foods, minimally processed foods, and culinary ingredients, although the rate of increase was lower than that observed in previous surveys (2002-2003 and 2008-2009 Consumer Expenditure Surveys) [3]. Social distancing has brought changes to food consumption, including a reduction in the intake of fruits and vegetables and an increase in that of ultraprocessed foods, such as chocolates, snacks, and frozen foods [2]. The preference for nonperishable foods as a means to reduce trips to retail food establishments has resulted in increased consumption of processed and ultraprocessed food products [4].

Supermarkets and restaurants have adopted strategies to ensure the safe production and distribution of food, including reinforcement of good hygiene and sanitation practices in-store and use of food delivery apps $[3,5]$. Food delivery services, however, do not come without risks, necessitating that consumers adequately sanitize food packaging before consumption. Furthermore, consumers are left with the responsibility of choosing reliable establishments that follow hygiene protocols [6].

Social distancing can be an opportunity to revive home cooking [6] and stimulate cooking skills as an enjoyable, stress-reducing practice. However, access to food and delivery services is not universal in Brazil, a country characterized by important socioeconomic and territorial differences. The economic crisis generated by the pandemic has worsened the health status of socioeconomically vulnerable groups, which include the majority of unemployed individuals and those who live in highrisk areas [4]. Social inequalities represent a major obstacle in the advance of public policies in food and nutrition in the country.

The Dietary Guidelines for the Brazilian Population address the importance of cooking skills for the development of healthy eating habits and reduction of processed and ultraprocessed food 
consumption [7]. The Food and Nutrition Education Framework highlights that prepare own meal can promote individual autonomy [8].

Although there is no consensus on the definition of cooking skills, the term can be conceptualized as "confidence, attitude, and application of individual knowledge to perform cooking tasks that range from planning menus and shopping to food preparation of unprocessed, minimally processed, processed, or ultraprocessed foods" [9]. The habit of preparing meals at home seems to be associated with healthy eating behaviors $[10,11]$. Thus, interventions aimed at developing cooking skills can contribute to healthy eating $[12,13]$.

In Brazil, the Nutrition in Foodservice Research Centre of the Federal University of Santa Catarina (NUPPRE-UFSC) has experience in performing studies on cooking skills. The group developed the Nutrition and Culinary in the Kitchen (NCK) program [14,15], a cooking intervention that was shown to improve the cooking skills of public university students in southern Brazil for up to six months. Although NCK program was aimed at university students, it was based on dietary recommendations for the general Brazilian population (individuals aged 2 years and older). The program can be adapted to Brazilians of other age groups or individuals with restricted diets, as has been performed by NUPPRE researchers [16]. The research group has also investigated the transmission of cooking skills between generations [17].

This article aims to present reflections on cooking skills in the context of the Covid-19 pandemic.

\section{HOME COOKING DURING THE COVID-19 PANDEMIC}

For a large part of the population, social distancing might have increased the need to use cooking skills for home meal preparation and to adopt a new food purchase routine. In a study carried out with 1005 individuals in the United States of America, more than half of the participants reported cooking more frequently than before the pandemic; of these, 50\% reported feeling more confident in the kitchen, $73 \%$ reported being fond of cooking, and $51 \%$ expressed their intention to continue to frequently cook at home after the pandemic [18].

Home cooking can be a strategy to gain control over diet quality and household budget, important factors in times of health and economic crises. However, lack of cooking skills, interest, and creativity, as well as high access to and availability of ready-to-eat foods, are barriers to home cooking $[17,19]$. An ongoing qualitative study by the NUPPRE group is following-up participants of the 2016 NCK intervention with Brazilian university students and the 2019 cooking classes for revisiting cooking skills $(n=18)$ to assess three-year impacts on the life of students [16]. Preliminary results indicate that social distancing, the need to work from home, willingness to try new recipes, greater availability, and increased confidence are favorable factors to home cooking, adding to the skills learned during the cooking intervention. However, lack of space, equipment, cooking utensils, and recipes are perceived by students as barriers to home cooking. One student reported that "now, in times of quarantine (...) I've been making food for two months and I'm already running out of recipes".

Social distancing has led influencers and chefs to stream cooking classes on social networks. Such videos can stimulate the practice of cooking skills, promote healthier eating $[20,21]$, and favor the exchange of culinary recipes between family and friends, reinforcing social connections and affective memories related to food [22]. 
Home cooking may reduce emotional stress resulting from the pandemic [23] and can be seen as a form of leisure and relaxation. It can also serve as an opportunity to develop and refine cooking skills $[18,19]$. However, the reality of Brazil is permeated by a vast history of inequalities, in terms of both income and access to food. During this pandemic period, social distancing directly affected the income of many Brazilian workers in rural and urban areas, increasing food insecurity [24]. Thus, for some people, cooking may not be associated with stress reduction; rather, it might represent an increase in the domestic workload, reinforced by social inequalities.

\section{IMPORTANCE OF COOKING SKILLDEVELOPMENT FOR RISK GROUPS}

Cardiovascular Diseases (CVD), Type 2 Diabetes Mellitus (T2DM) [25], and obesity [26] are among the risk factors for severe Covid-19. These health conditions are associated with inadequate nutrition [27].

The development of cooking skills can contribute to a healthier diet and assist in the treatment and prevention of CVD and T2DM. Cooking is recommended by national and international nutrition guidelines $[28,29]$ and regarded as an emancipatory practice capable of promoting autonomy and self-care [30]. Thus, in the current scenario, actions aimed at stimulating cooking skills in individuals at risk for Covid-19 are particularly important.

We highlight a previous study that adapted, tested, and evaluated the acceptance of culinary recipes aimed at individuals with T2DM for application in an NCK program. The use of herbs and spices was encouraged in detriment to that of added sugars and sweeteners [31]. The developed cooking recipes had a low glycemic index and load and were approved by individuals with T2DM. Recipes were incorporated into an NCK program for individuals with T2DM in a randomized controlled intervention study. Preliminary results showed adherence to in-person hands-on cooking classes. Currently, the researchers are evaluating adherence to the program and the impact of adaptation of hands-on cooking classes to online video classes because of the current pandemic context. This ongoing research can assist in the development of interventions aimed at risk groups.

\section{CONCLUSION}

The rescue of cooking skills in the current context of social distancing has been stimulated by social and media networks but still represents a challenge. At-home meal preparation can be a pleasant activity that promotes autonomy, self-care, and healthier eating habits for some individuals. However, lack of cooking skills, unemployment, social vulnerability, and lack of access to basic sanitation are barriers to home cooking.

As evidenced by the results of the NCK program and recommended by the Dietary Guidelines for the Brazilian Population, current public policies on food and nutrition such as the Política Nacional de Alimentação e Nutrição (PNAN, National Food and Nutrition Policy) should aim towards establishing programs for the evaluation and development of cooking skills and healthy eating habits, particularly for individuals of high-risk groups for Covid-19.

Thus, this study suggests that public policies should (1) incorporate cooking skills as a transversal element in the education guidelines for all age groups, including university students; (2) provide resources for the development cooking skills intervention programs, by hands-on cooking 
classes, with online possibility given the current pandemic period; (3) evaluate the impact of cooking skills intervention programs through validated instruments; and (4) define new target groups for the development of cooking skills in the context of the Sistema Único de Saúde (SUS, Unified Health System).

\section{A C KNOWLEDGMENTS}

We thank all those who participated in the studies that substantiated this technical note.

\section{CONTRIBUTORS}

PL UGGIONI, CMF ELPO, AC FERNANDES, APG GERALDO, AC MAZZONETTO, and GL BERNARDO were responsible for the study conception and interpreted the data and critically revised the manuscript. GL BERNARDO, CMF ELPO, AC FERNANDES, and PL UGGIONI collected the data. GL BERNARDO coordinated the research project Nutrição e Culinária na Cozinha (Nutrition and Culinary in the Kitchen).

\section{REFERENCES}

1. Ammar A, Brach M, Trabelsi K, Chtourou H, Boukhris O, Masmoudi L, et al. Effects of COVID-19 home confinement on eating behaviour and physical activity: results of the ECLB-COVID19 international online survey. Nutrients. 2020;12:1583. https://doi.org/10.3390/nu12061583

2. Fundação Oswaldo Cruz. CoVid: Pesquisa de Comportamentos. Rio de Janeiro: Fundação; 2020 [citado 5 jun 2020]. Disponível em: https://convid.fiocruz.br/index.php?pag=objetivos

3. Instituto Brasileiro de Geografia e Estatística. Pesquisa de orçamentos familiares 2017-2018: avaliação nutricional da disponibilidade domiciliar de alimentos no Brasil. Rio de Janeiro: Instituto; 2020 [citado 4 ago 2020]. Disponível em: https://biblioteca.ibge.gov.br/visualizacao/livros/iv101704.pdf

4. Oliveira TC, Abrances MV, Lana RM. (In)Segurança alimentar no contexto da pandemia por SARS-CoV-2. Cad Saúde Pública. 2020;36:1-6. https://doi.org/10.1590/0102-311x00055220

5. Food and Drug Administration (United States). Best practices for retail food stores, restaurants, and food pick-up/delivery services during the COVID-19 pandemic. Silver Spring: Administration; 2020 [cited 2020 June 17]. Available from: https://www.fda.gov/media/136811/download

6. World Health Organization. Food and nutrition tips during self-quarantine. Geneva: Organization; 2020 [cited 2020 June 17]. Available from: https://www.euro.who.int/en/health-topics/health-emergencies/ coronavirus-covid-19/technical-guidance/food-and-nutrition-tips-during-self-quarantine

7. Ministério da Saúde (Brasil). Guia alimentar para a população brasileira: promovendo a alimentação saudável. 2a. ed. Brasília: Ministério; 2014 [citado 4 ago 2020]. Disponível em: https://bvsms.saude.gov.br/ bvs/publicacoes/guia_alimentar_populacao_brasileira_2ed.pdf

8. Ministério do Desenvolvimento Social e Combate à Fome (Brasil). Marco de referência de educação alimentar e nutricional para as políticas públicas. Brasília; Ministério; 2012 [citado 4 ago 2020]. Disponível em: http:// www.mds.gov.br/webarquivos/publicacao/seguranca_alimentar/marco_EAN.pdf

9. Jomori MM, Vasconcelos FAG, Bernardo GL, Uggioni PL, Proença RPC. The concept of cooking skills: a review with contributions to the scientific debate. Rev Nutr. 2018;31:119-35. https://doi.org/10.1590/167898652018000100010

10. Laska MN, Larson NI, Neumark-Sztainer D, Story M. Does involvement in food preparation track from adolescence to young adulthood and is it associated with better dietary quality? Findings from a 10-year longitudinal study. Public Health Nutr. 2012;15:1150-8. https://doi.org/10.1017/S1368980011003004

11. Wolfson JA, Bleich SN. Is cooking at home associated with better diet quality or weight-loss intention? Public Health Nutr. 2015;18:1397-406. https://doi.org/ 10.1017/S1368980014001943

12. Reicks $M$, Koecher $M$, Reeder J. Impact of cooking and home food preparation interventions among adults: a systematic review (2011-2016). J Nutr Educ Behav. 2018;50:148-172. https.//doi.org/10.1016/j. jneb.2017.08.004 
13. Hasan B, Thompson WG, Almasri J, Wang Z, Lakis S, Prokop L, et al. The effect of culinary interventions (cooking classes) on dietary intake and behavioral change: a systematic review and evidence map. Bmc Nutr. 2019;5:29. https://doi.org/10.1186/s40795-019-0293-8

14. Bernardo GL, Jomori MM, Fernandes AC, Condrasky MD, Proença RPC. Nutrition and culinary in the kitchen program: a randomized controlled intervention to promote cooking skills and healthy eating in university students: study protocol. Nutr J. 2017;16:83. https://doi.org/10.1186/s12937-017-0305-y

15. Rita HAK, Bernardo GL, Jomori MM, Fernandes AC, Proença RPC. Desenvolvimento de receitas culinárias em um programa de intervenção com universitários brasileiros. Rev Nutr. 2018;31(4):397-411. https://doi. org/10.1590/1678-98652018000400005.

16. Bernardo GL, Jomori MM, Fernandes AC, Colussi CF, Condrasky MD, Proença RPC. Positive impact of an intervention in culinary skills in Brazilian university students: six months of follow-up of a randomized controlled study. Appetite. 2018;130:247-55. https://doi.org/10.1016/j.appet.2018.08.014

17. Mazzonetto AC, Le Bourlegat IS, Santos JLG, Spence M, Dean M, Fiates GMR. Finding my own way in the kitchen from maternal influence and beyond: a grounded theory study based on Brazilian women's life stories. Appetite. 2020;150:104677. https://doi.org/10.1016/j.appet.2020.104677

18. Hunter. Food Study Special Report: America gets cooking. New York: Hunter; 2020 [cited 2020 June 5]. Available from: https://www.hunterpr.com/foodstudy_coronavirus/

19. Mazzonetto AC, Dean M, Fiates GMR. Percepções de indivíduos sobre o ato de cozinhar no ambiente doméstico: revisão integrativa de estudos qualitativos. Ciên Saúde Coletiva. 2020 [forthcoming] [citado: 4 ago 2020]. http://www.cienciaesaudecoletiva.com.br/artigos/percepcoes-de-individuos-sobre-o-ato-decozinhar-no-ambiente-domestico-revisao-integrativa-de-estudos-qualitativos/17196?id=17196

20. Polak R, Finkelstein A, Paganoni S, Welch R, Silver JK. Cooking online with a chef: health professionals' evaluation of a live culinary coaching module. Nutr Metab Insights. 2019;12:1-5. https://doi.org/10.11 77/1178638819887397

21. Bramston V, Rouf $A$, Allman-Farinelli M. The development of cooking videos to encourage calcium intake in young adults. Nutrients. 2020;12:1236. https://doi.org/10.3390/nu12051236

22. Marino S. Cook it, eat it, Skype it: mobile media use in re-staging intimate culinary practices among transnational families. Int J Cult Stud. 2019;22:788-803. https://doi.org/10.1177/1367877919850829

23. Cullen W, Gulati G, Kelly BD. Mental health in the COVID-19 pandemic. Qjm. 2020;113(5):311-2. https:// doi.org/10.1093/qjmed/hcaa110

24. Silva-Filho OJ, Gomes-Júnior NNG. O amanhã vai à mesa: abastecimento alimentar e COVID-19. Cad Saúde Pública. 2020;36:e00095220. https://doi.org/10.1590/0102-311X00095220

25. Stein RA. COVID-19: risk groups, mechanistic insights and challenges. Int J Clin Pract. 2020;74:e13512. https://doi.org/10.1111/ijcp.13512

26. Abbas AM, Fathy SK, Fawzy AT, Salem AS, Shawky MS. The mutual effects of COVID-19 and obesity. Obes Med. 2020;19:100250. https://doi.org/10.1016/j.obmed.2020.100250

27. Afshin A, Sur PJ, Fay KA, Cornaby L, Ferrara G, Salama JS, et al. Health effects of dietary risks in 195 countries, 1990-2017: a systematic analysis for the Global Burden of Disease Study 2017. Lancet. 2019;393:1958-72. https://doi.org/10.1016/S0140-6736(19)30041-8

28. American Diabetes Association. Standards of medical care in diabetes 2019. Diabetes Care. 2019[cited 2020 Aug 4];44(Suppl1). Available from: https://care.diabetesjournals.org/content/diacare/suppl/2018/12/17/42. Supplement_1.DC1/DC_42_S1_2019_UPDATED.pdf

29. Sociedade Brasileira de Diabetes. Diretrizes da Sociedade Brasileira de Diabetes (2019-2020). São Paulo: Clannad; 2019 [citado 4 ago 2020]. Disponível em: https://www.diabetes.org.br/profissionais/images/ DIRETRIZES-COMPLETA-2019-2020.pdf

30. Byrne C, Kurmas N, Burant CJ, Utech A, Steiber A, Julius M. Cooking classes: a diabetes selfmanagement support intervention enhancing clinical values. Diabetes Educ. 2017;43:600-7. https://doi. org/10.1177/0145721717737741

31. Tiecher CV. Adaptação e testes de receitas culinárias do programa nutrição e culinária na cozinha para indivíduos com diabetes mellitus tipo 2 [dissertation]. Santa Catarina: Universidade Federal de Santa Catarina; 2019. 